\title{
Abnormalities of Serum Protein Electrophoresis in Cattle and Comparison between Assays for Markers of Inflammation and Markers of Liver Alteration
}

\author{
Ahmed Khiredine Metref ${ }^{1 *}$, Nedjma Aouane ${ }^{2}$, Djamila Kebour ${ }^{1}$ and Mohamed Melizi ${ }^{3}$ \\ ${ }^{1}$ Institute of Veterinary Sciences, University of Blida, Algeria; ${ }^{2} \mathrm{High}$ National Veterinary School of Algiers, Algeria \\ ${ }^{3}$ Agronomic, Veterinary Sciences Institute, Batna University, Algeria \\ *Corresponding author: makvetdz16211@gmail.com
}

Article History: $20-240 \quad$ Received: 07-Dec-20 Revised: 15-Jan-21 Accepted: 17-Jan-21
A B S TRACT
This study aims to prove the advantage to use blood serum electrophoresis (BSE) in medicine for cattle. For that, 200
animal's cases (healthy or diseased) were studied. We found, in order of importance: 47 cases of respiratory diseases, 7
cases of lameness, 9 cases of mastitis and 8 cases of metritis, the rest have developed inflammatory signs (hyperthermia,
low appetite) without any other specific clinical signs (15 subjects). The majority of animals reveal the highest ratio
A/G (Albumin/globulin). Alpha2 globulins were markedly high during bronchopneumonia. Most of the cattle had a low
value of the $\alpha 1$ globulins (3.67 $1.16 \mathrm{~g} / 1)$. The majority of cattle had a low value of the $\alpha 1$ zone in comparing with normal
range. Seven subjects have developed a monoclonal peak in hyper-gamma globulins. The fibrinogen concentrations did
not exceed the threshold of $5 \mathrm{~g} / 1$. The concentration of Haptoglobin was higher for only ten animals. The electrophoresis
of blood serum can replace the biochemical parameters used to determinate the alterations of the liver function: total
bilirubin, alkaline phosphatase (ALP) and gamma glutamyl transpeptidase (GGT). We found if the level of the $\alpha 2$ and
$\gamma$ globulins is highest; it gives the same interpretation for the animal's inflammation status like we have with the
increased level of haptoglobin observed for bronchopneumonia. For the other cases, like the insidious pathologies, they
are detected by the $\alpha 2$ and $\gamma$ globulins, but not by haptoglobin. Our study has proved that the use of blood serum
electrophoresis confirms the diagnosis of symptomatic pathologies and allows detecting asymptomatic pathologies.

Key words: ALP, Fibrinogen, Serum electrophoresis, GGT, Haptoglobin, Total Bilirubin.

@202I IJVS - All Rights Reserved

\section{INTRODUCTION}

Veterinarians must constantly adapt the needs of livestock development when the change in practice is most often at the expense of the basic rules of health safety. The current study was conducted in the Mitidja region, an agricultural region around the south of Algiers, Algeria.

The objective of this study is to reduce various known complementary clinical examination in bovine medicine, which are also expensive. At present, there are different methods of diagnosing clinical-express pathologies but very few that concern pathologies with low symptom specificity like the presence of liver abscesses (Macdonald et al. 2017) or subclinical expression of inflammatory reaction (Kaneko et al. 2008). Blood serum proteins are significant indicators of animal health. Nevertheless, several factors should be considered to appropriately interpret their concentrations in blood (Bobbo et al. 2017). Predicting the onset risk of these diseases has predominantly been based on a single blood parameter for a single disease, like Predicting periparturient disease risk is of immense value to the dairy industry (Ishikawa et al. 2020).

With this in mind, we have opted for the study of serum protein electrophoresis (SPE) to confirm its use as a means of diagnostics complementary to clinical examinations (Tóthová et al. 2017), rather than the dosage of inflammation proteins (acute phase proteins of inflammation): haptoglobin and fibrinogen (Humblet et al. 2004; Tóthová et al. 2015; Salem 2017) which are used in Bovine medicine and which also remains expensive.

In addition, we compare the results obtained with SPE and those obtained with biological parameters used to determine alterations in liver function (Smith 2009): total bilirubin, GGT and ALP.

\section{MATERIALS AND METHODS}

\section{Experimental Animals and Handling}

We took as a sample 200 animals indiscriminately, from 16 farms in the Mitidja region. Samples were collected

Cite This Article as: Metref AK, Nedjma A, Djamila K and Mohamed M, 2021. Abnormalities of serum protein electrophoresis in cattle and comparison between assays for markers of inflammation and markers of liver alteration. International Journal of Veterinary Science 10(3): 208-213. https://doi.org/10.47278/journal.ijvs/2021.038 
collected without any harm to the animals. All procedures with the animals were conducted in accordance with national guidelines for the care and use of animals and ethical standards of the Algerian institution. The study did not affect the normal physiology of animals.

\section{Collection of blood samples}

Blood was taken from the jugular vein and divided into three, i.e., i) without anticoagulant, ii) with citrate and iii) the last with heparin, then placed at $4^{\circ} \mathrm{C}$. All the farms are about $20 \mathrm{~km}$ away from the biochemical analysis laboratory. The samples were sent on the same day of sampling.

\section{Biochemical Determinations}

The blood sample was first centrifuged using a ROTOFIX 32 A (Hettich) ${ }^{\odot}$ centrifuge at $3000 \mathrm{rpm}$ for 10 min and collected serum stored at $-4^{\circ} \mathrm{C}$. The analyses were carried out on the biochemistry automaton "Cobas 6000 $(\mathrm{ROCHE})^{\odot "}$. The analysis of each parameter was carried out according to the technical recommendations of the designer: Roche diagnostics (method sheet) (2016). Haptoglobin (HP) was determined using the turbidimetry technique (Van Lente 1979). Fibrinogen (Fb) was determined using the Clauss method (Lowe 2004). For the liver functions, we used total bilirubin, GGT, and ALP. Evaluation of these parameters was carried out according to the enzymatic colorimetric method (Roche diagnostics (method sheet), 2016). Total proteins were determined using the Biuret method (Boyer 2000).

\section{Agarose Gel Electrophoresis (SEBIA Automaton; Gel Hydrasys) ${ }^{\odot}$ \\ This analysis was performed according to the principle} described by Lecarrer (1994); Jania and Andraszek (2016). This operation was performed by the HYDRASYS ${ }^{\circledR}$ semiautomatic system. It allows all sequences to be carried out until the gel is ready for qualitative or quantitative analysis. The separated proteins were stained by an Amidoschwarz solution and the excess dye was removed in an acid medium. Electrophoresis profiles were analyzed visually to detect anomalies. The use of the automatons to carry out the analyses allowed us to obtain a greater number of results at the same time, (30 samples were analyzed in $25 \mathrm{~min}$ for electrophoresis, 50 samples were analyzed for other biochemical parameters in less than 30min).

\section{Clinical Data Collection}

Without conditioning, all cattle present on the farms were included in this study. For each animal an individual data sheet was made and we mentioned the clinically suspected pathology. The range of normal values of clinical chemistry was taken as cited by Smith (2009). The definitive diagnosis is only made after reading and interpreting the results of the biochemical analyses, associating with the clinical data.

\section{Statistical analysis}

The IBM SPSS ${ }^{\circledR}$ statistics software, version 20 was used to perform the statistical analysis.

\section{RESULTS}

We found, in order of importance: 47 cases of respiratory diseases, 7 cases of lameness, 9 cases of mastitis and 8 cases of metritis, the rest have developed inflammatory signs (hyperthermia, low appetite) without any other specific clinical signs (15 subjects). All of them recorded an increase of $\alpha 2$ and/or $\gamma$ globulins (Table 1). The serum proteins electrophoresis obtained a plot comprising 5 fractions: The first fraction from the left is represented by albumin, followed by $\alpha 1, \alpha 2, \beta, \gamma$ globulins. In the physiological state, there is a clear gap between the end of the 2 fraction and the end of the $\beta$ globulin fraction. We distinguished the particularity of six clinical cases than all.

Fig. 1 shows the case of a 10-year-old cow with chronic mammary disease. The clinical expression was explicit: inflammatory signs, denatured milk. Protein analysis revealed a peak of $\gamma$ globulins $(40.04 \mathrm{~g} / \mathrm{l})$.

Fig. 2 shows the case of an 8-year-old cow with a mammary inflammation and bronchopneumonia. She developed abnormal respiratory noise with nasal purulent discharge. The biochemistry revealed an increase in the following parameters: GGT (40UI/l), ALP (181UI/l), HP $(0.54 \mathrm{~g} / \mathrm{l})$ and $\gamma$ globulins $(25.38 \mathrm{~g} / 1)$, controls for liver disease and inflammation, respectively.

Fig. 3 shows the case of a cow, aged 2 years, with a pattern characterized by the formation of a block $(\beta-\gamma)$. Clinical signs revealed hyper-salivation with no appetite, dehydration (persistence of the skin fold and drying of the mucous membranes) and slight hyperthermia. She had rumen acidosis associated with liver disease (presence of the block $(\beta-\gamma))$, revealed by an increase in protein $(95 \mathrm{~g} / \mathrm{l})$, total bilirubin $(8 \mathrm{~g} / \mathrm{l}), \alpha_{2}$ globulins $(9.75 \mathrm{~g} / \mathrm{l}), \gamma$ globulins $(30.02 \mathrm{~g} / \mathrm{l})$.

Fig. 4 shows the case of a 6 -year-old cow, with liver failure revealed by biochemistry: increase in total proteins (107g/1), $\alpha 2$ globulins $(10.7 \mathrm{~g} / \mathrm{l}), \gamma$ globulins $(34.03 \mathrm{~g} / \mathrm{l})$, ALP (247UI/1), GGT (51UI/1).

Fig. 5 describes the case of a 6-year-old cow with bronchopneumonia associated with liver disease revealed by biochemistry: increase in $\alpha 2$ globulins $(11.78 \mathrm{~g} / 1), \beta$ globulins (11.78g/l), $\gamma$ globulins (57.66g/1), ALP (198UI/1), GGT (106UI/l), total protein $(124 \mathrm{~g} / \mathrm{l})$.

Fig. 6 represents the SPE plot of a heifer suffering from rumen acidosis associated with liver alteration. It was also an asymptomatic pathology revealed by clinical biochemistry. It is characterized by an increase in total proteins $(106 \mathrm{~g} / \mathrm{l})$ which often follows cases of acidosis, globulins $\alpha 2(11.55 \mathrm{~g} / 1)$, globulins $\gamma(11.02 \mathrm{~g} / \mathrm{l})$, which are controls of inflammation, globulins $\beta(40.39 \mathrm{~g} / \mathrm{l})$, ALP (161UI/l), GGT (274UI/l).

Seven (7) subjects have developed a monoclonal peak in hyper-gamma globulins (narrow and homogeneous). This is the case of the calves under 6 months old (Fig. 7).

\section{DISCUSSION}

For the first three of the abnormal plots, serum protein analysis allowed us to support the clinical diagnosis, described in Fig. 1, Fig. 2 and Fig. 3. We found for the first and second cases (see Fig. 1 and Fig. 2), the $\alpha 2$ and $\gamma$ globulins are good markers of inflammation like this explained by Tóthová et al. (2017). The case in Fig. 3, the SPE revealed the liver alteration associated with the rumen acidosis, the same clinical case was reported by Piccione et al. (2012). 
Int J Vet Sci, 2021, 10(3): 208-213.

Table 1: Statistical analysis of blood serum electrophoresis parameters

\begin{tabular}{llcccccccc}
\hline & & $\mathrm{N}$ & Average & $\mathrm{SD}$ & $\mathrm{SE}$ & \multicolumn{2}{c}{ 95\% Confidence Interval for the average } & Minimum & Maximum \\
\cline { 8 - 9 } Total Protein & Sick & 114 & 74.5000 & 19.14280 & 1.79289 & 70.9480 & 78.0520 & 0.00 & 124.00 \\
& Healthy & 86 & 71.1163 & 18.87196 & 2.03502 & 67.0701 & 75.1624 & 34.00 & 145.00 \\
& Total & 200 & 73.0450 & 19.05330 & 1.34727 & 70.3882 & 75.7018 & 0.00 & 145.00 \\
Albumin & Sick & 114 & 31.6310 & 8.90287 & 0.83383 & 29.9790 & 33.2829 & 0.00 & 50.95 \\
& Healthy & 86 & 32.9031 & 8.61093 & 0.92854 & 31.0570 & 34.7493 & 11.56 & 62.59 \\
& Total & 200 & 32.780 & 8.77938 & 0.62080 & 30.9538 & 33.4022 & 0.00 & 62.59 \\
ALB/GLB & Sick & 114 & 0.7942 & 0.27538 & 0.02579 & 0.7431 & 0.8453 & 0.00 & 1.40 \\
& Healthy & 86 & 0.9560 & 0.31092 & 0.03353 & 0.8894 & 1.0227 & 0.21 & 1.71 \\
Alpha1glob & Total & 200 & 0.8638 & 0.30134 & 0.02131 & 0.8218 & 0.9058 & 0.00 & 1.71 \\
& Sick & 114 & 3.7684 & 1.18879 & 0.11134 & 3.5478 & 3.9890 & 0.00 & 7.72 \\
& Healthy & 86 & 3.5509 & 1.12807 & 0.12164 & 3.3091 & 3.7928 & 1.39 & 8.85 \\
Alpha2glob & Total & 200 & 3.6749 & 1.16520 & 0.08239 & 3.5124 & 3.8374 & 0.00 & 8.85 \\
& Sick & 114 & 7.6192 & 2.10126 & 0.19680 & 7.2293 & 8.0091 & 0.00 & 12.57 \\
& Healthy & 86 & 7.2634 & 2.16091 & 0.23302 & 6.8001 & 7.7267 & 3.77 & 13.78 \\
Betaglob & Total & 200 & 7.4662 & 2.12906 & 0.15055 & 7.1693 & 7.7631 & 0.00 & 13.78 \\
& Sick & 114 & 6.0431 & 1.83632 & 0.17199 & 5.7023 & 6.3838 & 0.00 & $11 . .8$ \\
& Healthy & 86 & 5.8705 & 1.75750 & 0.18952 & 5.4937 & 6.2473 & 2.20 & 13.05 \\
Gammaglob & Total & 200 & 5.9688 & 1.80041 & 0.12731 & 5.7178 & 6.2199 & 0.00 & 13.05 \\
& Sick & 114 & 25.4366 & 11.53066 & 1.07994 & 23.2970 & 27.5761 & 0.00 & 61.27 \\
& Healthy & 86 & 21.5297 & 11.31605 & 1.22024 & 19.1035 & 23.9558 & 7.52 & 73.23 \\
& Total & 200 & 23.7566 & 11.57383 & 0.81839 & 22.1428 & 25.3704 & 0.00 & 73.23 \\
\hline
\end{tabular}

Table 2: Statistical analysis of hepatic alteration markers

\begin{tabular}{|c|c|c|c|c|c|c|c|c|c|}
\hline \multirow[t]{2}{*}{ Parameters } & & \multirow[t]{2}{*}{$\mathrm{N}$} & \multirow[t]{2}{*}{ Average } & \multirow[t]{2}{*}{ SD } & \multirow[t]{2}{*}{ SE } & \multicolumn{2}{|c|}{ 95\% Confidence Interval for the average } & \multirow[t]{2}{*}{ Minimum } & \multirow[t]{2}{*}{ Maximum } \\
\hline & & & & & & Lower terminal & Top terminal & & \\
\hline ALP & Sick & 114 & 93.24 & 69.200 & 6.481 & 80.40 & 106.08 & 20 & 400 \\
\hline \multirow[t]{2}{*}{ (IU/l) } & Healthy & 86 & 111.90 & 89.177 & 9.616 & 92.78 & 131.01 & 19 & 431 \\
\hline & Total & 200 & 101.26 & 78.751 & 5.569 & 90.28 & 112.24 & 19 & 431 \\
\hline GGT & Sick & 114 & 26.82 & 15.819 & 1.482 & 23.88 & 29.75 & 1 & 106 \\
\hline \multirow[t]{2}{*}{ (IU/l) } & Healthy & 86 & 27.87 & 30.313 & 3.269 & 21.37 & 34.37 & 9 & 274 \\
\hline & Total & 200 & 27.27 & 23.127 & 1.635 & 24.05 & 30.49 & 1 & 274 \\
\hline & Sick & 114 & 1.82 & 1.393 & 0.130 & 1.56 & 2.07 & 0 & 9 \\
\hline \multirow{2}{*}{$(\mathrm{g} / \mathrm{l})$} & Healthy & 86 & 1.66 & 1.047 & 0.113 & 1.44 & 1.89 & 0 & 6 \\
\hline & Total & 200 & 1.75 & 1.255 & 0.089 & 1.57 & 1.93 & 0 & 9 \\
\hline
\end{tabular}

GGT (Gamma Glutamyl transpeptidase) and ALP (Alkaline phosphatase).

Table 3: Statistical analysis of Acute Phase Inflammation Markers

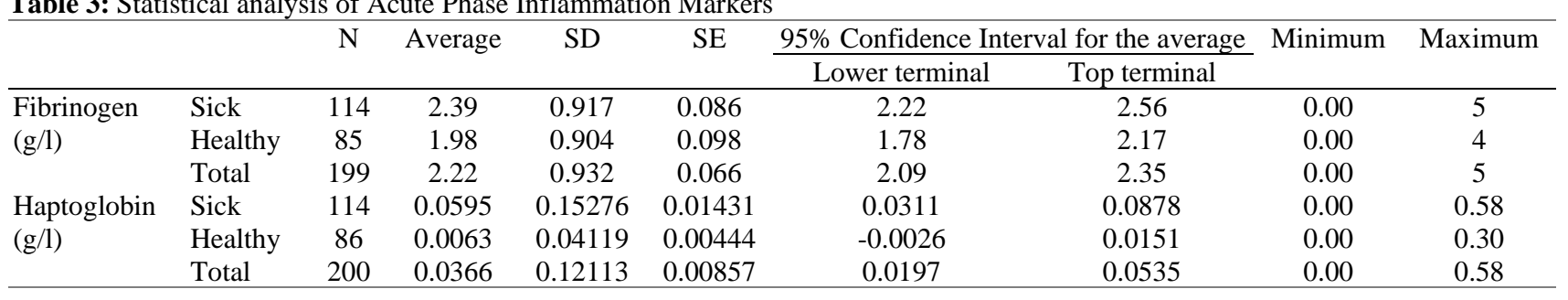

The other three cases (Fig.4, Fig.5 and Fig.6) represent inflammatory conditions that were not apparent but were revealed by biochemical analysis (Table 1 and Table2: results for sick's animals), the same clinical case was described by Tóthová et al. (2017). The results obtained by electrophoresis permit the interpretation of these clinical cases associated with the data collected for each. It is possible to confirm clinically apparent cases and to discover other asymptomatic cases. For example, we can confirm the diagnosis of the alteration liver, based on the results shown in Fig. 4 and this disease is discovered for other, without pathological signs, based on the results shown in Fig.6.

For the subject shown in Fig.7, the monoclonal peak is consecutive of the antibodies synthesis usually directed against specific antigens caused by viral attacks, bacterial or parasitic, like explained by Lecarrer (1994). The influence of age specifically for $\mathrm{IgG}$ is explained by Souza et al. (2019). As a result, the poor overweight condition of these young animals is explained. This observation is never been reported before for young calves. By elsewhere, the presence of monoclonal peak for this species is cited by Kaneko et al. (2008); Smith (2009) concerns the older cattle above 6 months sufferings by lymphocytic leukemia or endothelial tumor.

The majority of animals revealed a highest ratio $\mathrm{A} / \mathrm{G}$, indicating high synthesis of albumin, which is part of hyperproteinemia, caused by rumen acidosis (Smith, 2009) resulting from a food imbalance, observed in the several farms. The same cases to have subclinical ketosis are cited by Ishikawa et al. (2020).

Elsewhere, it is caused by the decrease of albumin may refer to weight loss (transition cow period), a consequence of malnutrition (insufficient types of diets). Moreover, the decrease of albumin is considered a negative marker of inflammation (Piccione et al.2012; Rodrigues et al. 2018). 
Int J Vet Sci, 2021, 10(3): 208-213.

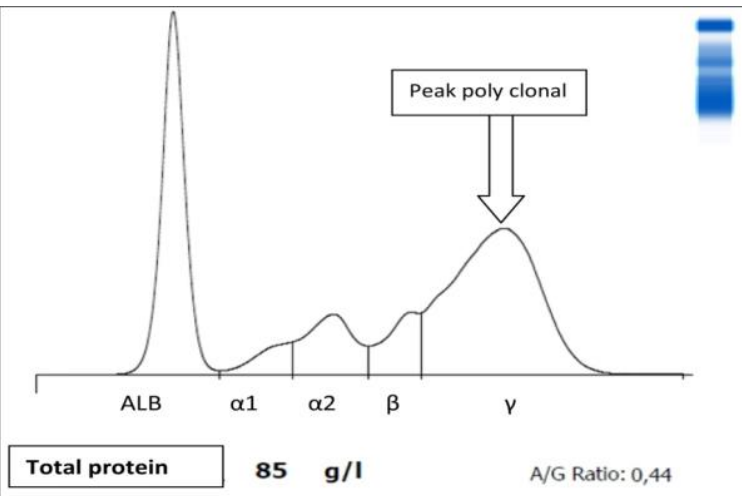

Fig. 1: Plot of blood serum electrophoresis of cow with chronic mastitis.

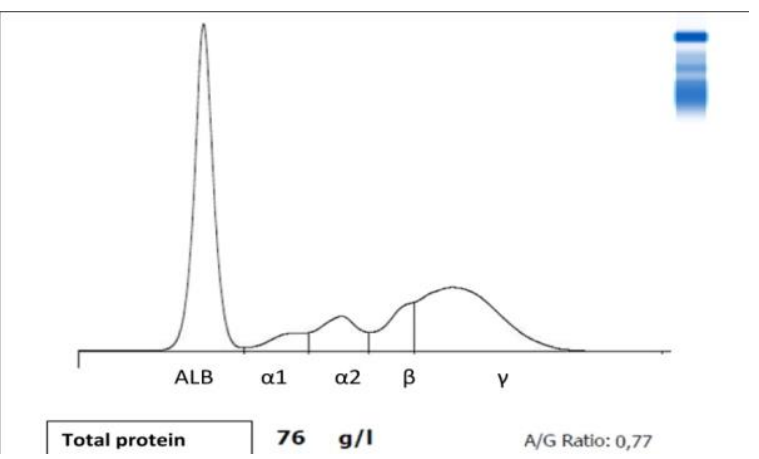

Fig. 2: Plot of blood serum electrophoresis of cow with mastitis associated bronchopneumonia.

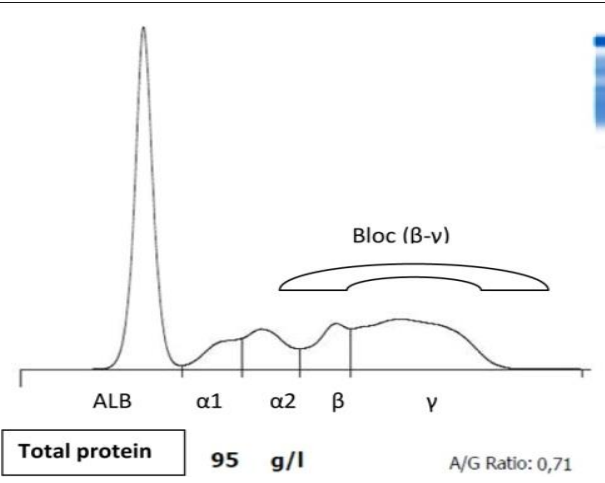

Fig. 3: Plot of blood serum electrophoresis of cow with rumen acidosis and liver alteration.

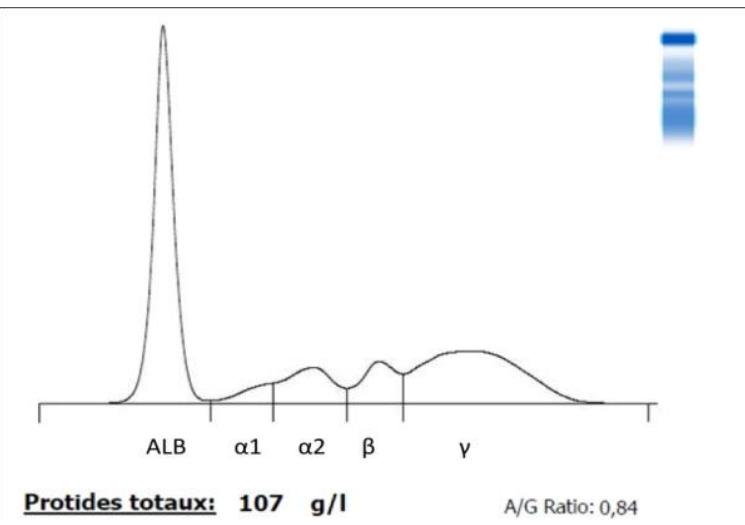

Fig. 4: Plot of blood serum electrophoresis of cow with liver alteration.

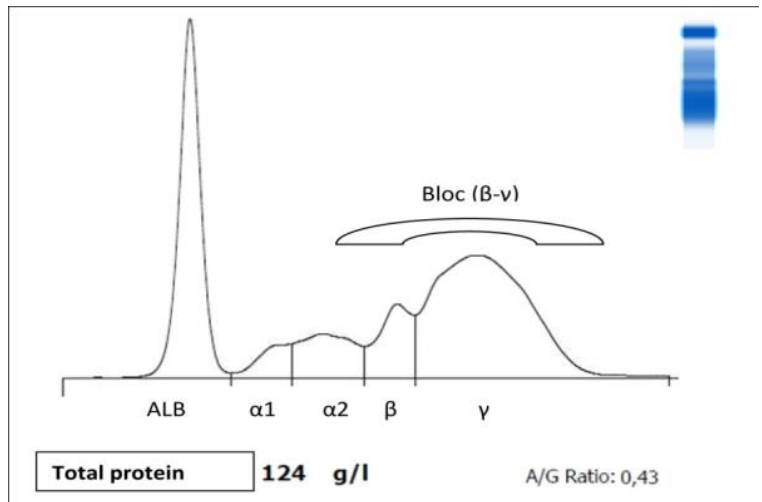

Fig.5: Plot of blood serum electrophoresis of cow with liver alteration and bronchopneumonia.

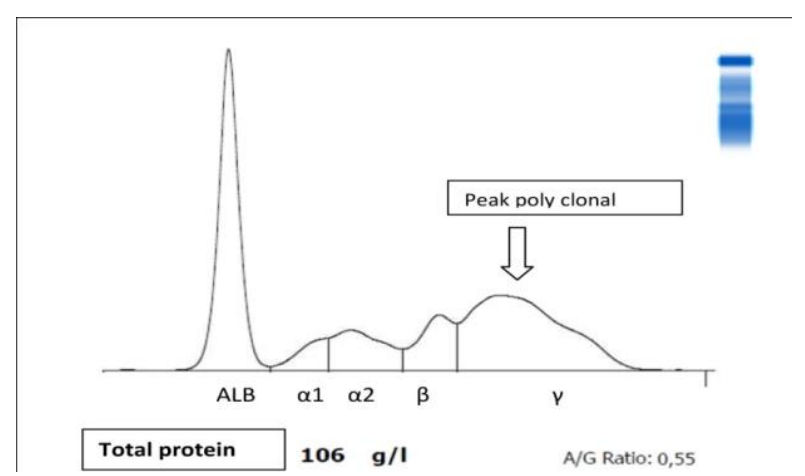

Fig. 6: Plot of blood serum electrophoresis of cow with rumen acidosis.

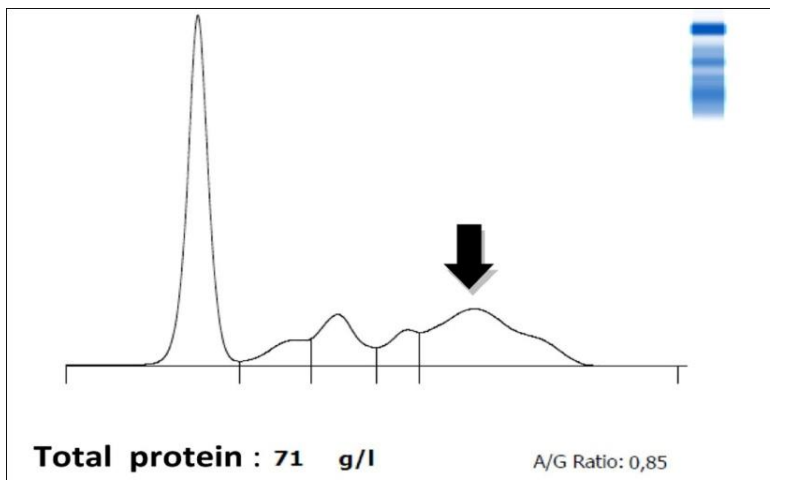

Fig. 7: Plot of blood serum electrophoresis of young bull, 6 months old, delayed growth.

Moreover, the subclinical pathology with the chronic evolution had a peculiar effect on the bovine gamma globulin (Jacobsen et al. 2004). In general, however, albumin decreases, and globulin increases in response to stress (Smith 2009; Kekana et al. 2018).

Our results supported the conclusion of Jania and Andraszek (2016), many diseases processes are associated with abnormal serum protein profiles. Changes in the protein profile often occur as secondary symptoms in many diseases, but they may also be the primary symptom of specific disease states (Table 1).

The fibrinogen dosage will reveal that its value will never exceed the $5 \mathrm{~g} / 1$ threshold (Table 2). This has also been observed for sick subjects who express clinical signs. As a result, this parameter was found to be less sensitive to 
inflammation compared to electrophoresis. This is the consequence of the negative energy balance; caused by the inexistence of rationing feed techniques adapted for animal production (Kaneko et al. 2008; Smith 2009; Tóthová et al. 2014).

Only 10 cows have a Haptoglobin level higher than $0.41 \mathrm{~g} / \mathrm{l}$ (Table 3). This specific Haptoglobin sensitivity revealed the respiratory inflammation, they have bronchopneumonia and belong to the same herd, the same results were cited by Humblet et al. (2004); Berry et al. (2005). The rest of the cattle had no significant values of Haptoglobin (Ceciliani et al. 2012).

The majority of cattle had a low value of the $\alpha 1$ zone (Table 1) in comparison with normal range (Smith 2009), we had a low wave, without specific clinical manifestations. The study has not been able to determine the cause of this cases, for thus we suggested the hypothesis of a congenital origin of $\alpha 1$ antitrypsin deficiency [the major protein of $\alpha 1$ zone (Smith 2009)]. However, in cattle, the serum levels of $\alpha 1$-antitripsin can be so low that their systemic detection is difficult (Di Filippo 2018). In humans it described by Denden et al. (2010), or it's the result to an impairment of the respiratory system as described by Tuder et al. (2010), Janciauskiene et al. (2011). This anomaly reported in humans, has not been previously revealed in ruminants. Only the CSF in cattle (the cerebrospinal fluid) presented $\alpha 1$-antitripsin (Fagliari et al. 2007; Sampaio et al. 2015; Di Filippo 2018).

\section{Conclusion}

Electrophoresis alone can provide an answer to many clinical diagnostic problems. Its interpretation in combination with the data collected for each individual has made it possible to confirm clinically apparent cases and to discover other asymptomatic cases. We can consider serum protein electrophoresis as a practical tool for diagnosis in rural medicine: the ease of its realization, the simplicity of its method, the rapidity of its response (less than one hour), the quality of its information.

This tool can replace the biochemical parameters used to determinate the alterations of the liver function: Total bilirubin, GGT, and ALP. We found if the level of the $\alpha 2$ and $\gamma$ globulins is highest, it gives the same interpretation for the animals inflammation status like we have with the increased level of Haptoglobin (the main acute phase protein marker of inflammation), like observed for bronchopneumonia. For the other cases, like the insidious pathologies, they are detected by the $\alpha 2$ and $\gamma$ globulins, but not by Haptoglobin (Fig 4, Fig 5, Fig 6). Electrophoresis thus constitutes a practical and economical alternative in the medicine of ruminants in order to confirming the diagnosis and formulating a more accurate prognosis.

\section{Author's Contributions}

AKM conceived and designed the study, performed the laboratory analyses, collected samples, has given the final approval of the version to be published. DK performed the statistical analyses, contributed in the interpretation of data. NA and MM drafted the manuscript and revised the manuscript critically. All authors read and approved the final manuscript.

\section{REFERENCES}

Berry EA, Hillerton JE, Hett B and Harte D, 2005. Measuring milk quality by milk amyloïd. The 5th International Colloquium on Animal, Acute Phase Proteins, Dublin, Ireland March $14^{\text {th }}-15^{\text {th }}$.

Boyer R, 2000. Modern Experimental Biochemistry. $3^{\text {rd }}$ Ed. Addison Wesley Longmanc Inc, California, USA, pp: 475.

Bobbo T, Fiore E, Gianesella M, Morgante M, Gallo L, Ruegg P L, Bittante G and Cecchinato A, 2017. Variation in blood serum proteins and association with somatic cell count in dairy cattle from multi-breed herds. Animal 11: 2309-2319. http://doi.org/10.1017/S1751731117001227

Ceciliani F, Ceron JJ, Eckersall PD and Sauerwein H, 2012. Acute phase proteins in ruminants. Journal of Proteomics 75: 4207 4231. https://doi.org/10.1016/j.jprot.2012.04.004

Denden S, Lakhdar R, Leban N, Daimi H, Elhayek D, Knani J, Perrin P, Lefranc G, Benchibani J and khelil AH, 2010 Development: alpha 1 antitrypsin deficiency. Mediterranean Journal of Human Genetics 1: 26-33.

Di Filippo PA, Lannes ST, Meireles MAD, Nogueira AFS, Ribeiro LMF, Graça FAS and Glória LS, 2018. Acute phase proteins in serum and cerebrospinal fluid in healthy cattle: possible use for assessment of neurological diseases. Brazilian Journal of Veterinary Research 38: 779-784. http://doi.org/ 10.1590/1678-5150-PVB-5093

Fagliari JJ, Passipieri M, Okuda HQ, Silva SL and Silva PC, 2007. Serum protein concentrations, including acute phase proteins, in calves with hepatogenous photosensitization. Arquivo Brasileiro de Medicina Veterinária e Zootecnia. 59: 1355-1358. http://dx.doi.org/10.1590/S0102-09352007 000600001 .

Humblet MF, Coghe J, Lekeux P and Godeau JM, 2004. Acute phase proteins assessment for an early selection of treatments in growing calves suffering from bronchopneumonia under field conditions. Research Veterinary Sciences 77: 41-47. https://doi.org/10.1016/j.rvsc.2004.02.009

Ishikawa S, Ikuta K, Obara Y, Oka A, Otani Y, Takahashi Y, Bai $\mathrm{H}$ and Terada $\mathrm{F}$ and Kushibiki, 2020. Cluster analysis to evaluate disease risk in periparturient dairy Cattle. Japanese Society of Animal Science 2020: 91. http://Doi.org/ 10.1111/asj. 13442

Jacobsen S, Andersen PH, Toelboel T and Heegaard PMH, 2004. Dose dependency and individual variability of the lipopolysaccharide-induced bovine acute phase protein response. Journal Dairy Science 87: 3330-3339. https://doi.org/10.3168/jds.S0022-0302(04)73469-4

Janciauskiene SM, Bals R, Koczulla R, Vogelmeier C, Köhnlein $\mathrm{T}$ and Welte $\mathrm{T}, 2011$. The discovery of $\alpha 1$-antitrypsin and its role in health and disease. Respiratory Medicine 105: 11291139. https://doi.org/10.1016/j.rmed.2011.02.002

Jania B and Andraszek K, 2016. Application of native agarose gel Electrophoresis of serum proteins in veterinary diagnostics. Journal of Veterinary Research 60: 501-508. https://doi.org/ $\underline{10.1515 / \text { jvetres-2016-0074 }}$

Kaneko JJ, Harvey JW and Bruss ML, 2008. Clinical Biochemistry of Domestic Animals. $6^{\text {th }}$ Ed, Academic Press, pp: 928.

Kekana TW, Nherera-Chokuda FV, Muya MC, Manyama1 K M and Lehloenya K C, 2018. Milk production and blood metabolites of dairy cattle as influenced by thermal-humidity index. Tropical Animal Health and Production 50: 921-924. https://doi.org/10.1007/s11250-018-1513-y

Lecarrer D, 1994. Serum protein electrophoresis immunefixation, 125p: 11-31, Publisher: SEBIA (INC)

Lowe GD, Rumley A and Mackie IJ, 2004. Plasma fibrinogen. Annal of Clinic Biochemistry 41: 430-440. https://doi.org/ $\underline{10.1258 / 0004563042466884}$ 
Int J Vet Sci, 2021, 10(3): 208-213.

Macdonald AGC, Bourgon SL, Palme R, Miller SP and Montanholi YR, 2017. Evaluation of blood metabolites reflects presence or absence of liver abscesses in beef cattle. Veterinary Record Open 2017: 4. http://doi.org/10.1136/ vetreco-2016-000170

Piccione G, Messina V, Alberghina D, Giannetto C, Caselle S and Assenza A, 2012. Seasonal variations in serum protein fractions of dairy cows during different physiological phases. Comparative Clinical Pathology 21: 1439-1443. https://doi 10.1007/s00580-011-1311-7

Riond B, Wenger-Riggenbach B, Hofmann-Lehmann R and Lutz $\mathrm{H}, 2009$. Serum Protein concentrations from clinically healthy horses determined by agarose gel electrophoresis. Veterinary Clinical Pathology 38: 73-77. https://doi.org: 10.1111/j.1939-165X.200800100.x

Roche Dignostics, 2016. (Method Sheets). https://dialog1.roche. com/pi/en_us/elabdoc, (accessed 2016).

Rodrigues CA, Santos PSP, Feitosa FL F, Perri SV, Lisboa J N, Teodoro PHM, De Araújo MA and Filho MNV, 2018. Serum immunoglobulin from Nellore cattle produced by in vitro fertilization and treated for umbilical diseases. Brazilian Journal of Veterinary Research 38: 256-261. http://doi.org/10.1590/1678-5150-PVB-4899

Salem NY, 2017. Effect of lactation on hemato-biochemical and minerals constituents in small ruminant. International Journal of Veterinary Science 6: 53-56.

Smith BP, 2009. Large Animal Internal Medicine. $4^{\text {th }}$ Ed. Mosby Elsevier, St. Louis, Missouri, USA; pp: 375- 447.
Sampaio PH, Fidelis JOL, Marques LC, Machado RZ, Barnabé PA, André MR, Balbuena TS and Cadioli FA, 2015. Acutephase protein behavior in dairy cattle herd naturally infected with Trypanosoma vivax. Veterinary Parasitology 211:141 145. http://dx.doi.org/10.1016/j.vetpar.2015.05.014. PMid: $\underline{26012859}$.

Souza DC, Silva DG, Rocha TG, Monteiro BM, Pereira GT, Fiori LC, Viana RB and Fagliari JJ, 2019. Serum biochemical profile of neonatal buffalo calves. Arquivo Brasileiro de Medicina Veterinária e Zootecnia 71: 187-196. http://dx.doi.org/10.1590/1678-4162-10176

Tóthová CS, Mudroň P and Nagy O, 2017. The electrophoretic pattern of serum proteins in dairy cows with inflammatory diseases. Acta Veterinaria Beograd 67: 178-190. https://doi.org/10.1515/acve-2017-0016

Tóthová CS, Nagy O and Kováč G, 2014. Acute phase proteins and their use in the diagnosisof diseases in ruminants. Veterinární Medicína 59: 163-180.

Tóthová CS, Nagy O, Nagyová V and Kováč G, 2015. Changes in the concentrations of acute phase proteins in calves during the first month of life. Acta Veterinaria Beograd 65: 260270. https://doi.org/10.1515/acve-2015-0022

Tuder RM, Janciauskiene SM and Petrache I, 2010. Lung disease associated with $\alpha 1$-antitrypsin deficiency. Proceedings of the American Thoracic Society 7: 381-386.

Van Lente F, Marchand A and Galen RS, 1979. Evaluation of a nephelometric assay for haptoglobin and its clinical usefulness. Clinical Chemistry 25: 2007-2010. https://doi. org/10.1093/clinchem/25.12.2007 